\title{
A BUDAPESTI AGGLOMERÁCIÓ KÖZLEKEDÉSI ELÉRHETŐSÉGI VIZSGÁLATA
}

ANALYSIS OF BUDAPEST AGGLOMERATION TRANSPORT ACCESSIBILITY

\author{
Jekli Roland ${ }^{1}$, Péli László ${ }^{2}$ \\ ${ }^{(1)}$ MA hallgató, ${ }^{(2)}$ adjunktus \\ Gazdaság- és Társadalomtudományi Kar, Szent István Egyetem \\ E-mail: jekli.roland@gmail.com, Peli.Laszlo@gtk.szie.hu
}

\section{Összefoglalás}

Magyarország a XIX.-XX. századtól kezdődően - hasonlóan a nyugat-európai térséghez - a polgári fejlődés útjára lépett. Ezen belül Budapest, az ország fővárosaként a kedvező természeti adottságok mellett a társadalmi-gazdasági és a közlekedési potenciáljának köszönhetően a Kárpát-medence domináns szereplöjévé vált. A centrumtérség körül törvényszerüen kialakuló agglomerációs települések lakossági és gazdasági szempontból is erősen kötődnek a városhoz, ahol a közlekedési elérhetőséget vizsgáltam.

\begin{abstract}
From the XIX-XX. century, Hungary - similar to the Western European region - took the path of civil development. Budapest, the capital city of the country has become a dominant character in the Carpathian Basin by favorable natural and socio-economic conditions, as well as transport potential. I investigated the traffic accessibility of the unavoidably formed suburbs, which is strongly tied to the city in population and economic aspects.
\end{abstract}

Kulcsszavak: közlekedéstörténet, közlekedési eszközök, elérhetőségi vizsgálat, budapesti agglomeráció, szuburbanizáció

JEL besorolás: $\mathrm{R} 41$

LCC: GR865-874

\section{Bevezetés}

A közlekedéstudomány egy rendkívül széles körü, a közlekedéshez kapcsolódó ismeretek integrálásával és kutatásával foglalkozó szakterület, amelynek egyik legfontosabb feladata a helyváltoztatási folyamatok vizsgálata. Meghatározását tekintve a közlekedés a személyeknek, tárgyaknak, gondolatoknak (információk) speciális technikai eszközök segítségével véghezvitt, rendszeres és szervezett helyváltoztatása (szállítása, forgalma).

Az európai térségben a polgári átalakulás - amely egyesek szerint kedvező, mások szerint kedvezőtlen folyamatokat hordozott magában - a gazdaságban új módszerek bevezetését jelentette, amelyeket - időben és hatékonyságában - eltérő ütemben vezettek be. Ennek természetesen Magyarország - ezen belül pedig a fóváros és annak térsége is - a részese volt, ahol szintén előtérbe került a személyek és az áruk helyváltoztatásának jelentősége és egyben felértékelödött a közlekedés fontossága. Bár hazánk távol esett a nyugat-európai ipari centrumtérségtől és ebből fakadóan fokozottan jelentkeztek a közlekedési hálózat alacsony teljesítőképességéből eredő problémák, késve ugyan, de a XIX. század második felére Magyarországnak is sikerült ezeket a nehézségeket leküzdenie. Napjaink gazdasági-társadalmi életének egyik legfontosabb jellemzőjévé a mobilitás vált. Ennek keretében, a modernizációs 
folyamatokat figyelembe véve, szinte valamennyi cselekedetünket, tevékenységünket, lépésünket, akarva-akaratlanul meghatározza a közlekedési és információs ágazat, annak minden kedvező és kedvezőtlen tulajdonságával együtt. Vizsgálatunk központi témaköre a Közép-magyarországi régióban található budapesti agglomeráció közlekedési szempontú elérhetőségi tanulmányozása. Kutatásunkban választ kívántunk adni egy világváros mindennapjait érintő olyan rövid- és hosszú távú változásra, amely a gazdasági növekedés egyik motorjának tekinthetö.

\section{Anyag és módszertan}

\section{Kutatási elözmények}

Kutatásunkban a 89/1997. Kormányrendelet (V. 28) által megállapított területi besorolást vettem alapul, amelyet a Központi Statisztikai Hivatal tanulmánya osztott fel összesen 6 szektorra, az 1990. évi népszámlálási és az 1991-1994 közötti statisztikai és tervezési célú adatfelvételeket összegezve. A rendeletben foglaltak szerint az önálló vonzáskörzettel rendelkező települések (pl.: Gödöllő, Vác, Szentendre, Érd) is az agglomeráció részét képezik.

A fö- és gyorsforgalmi úthálózat nyomvonalai a térszerkezetet és közlekedési elérhetőséget nagymértékben meghatározzák, ezért kiemelt figyelmet fordítottunk ezeknek a tényezőknek a vizsgálatára. Pest megye az országos hálózatban fontos tranzit szereppel rendelkezik, ahol a személy- és áruforgalom leginkább átmenő forgalmat jelent a közutakon. A megye közlekedési hálózata főváros központú és sugaras struktúrájú, ahol az egyetlen lényegesebb transzverzális irányú kapcsolatot az M0 autóút déli, keleti és északi szektora biztosítja. A régión belül a 2707 km hosszú közúthálózatból 233 km gyorsforgalmi út (M0, M1, M2, M3, M5, M6, M7), 257 km elsőrendű föút és $270 \mathrm{~km}$ föút nyújt kényelmes és a napszaktól függően gyors eljutást a települések között.

Kutatásunkban a hat agglomerációs szektor közösségi, valamint egyéni közlekedési elérhetőségi táblázatait készítettem el. Elemzésünket egy tetszőlegesen kiválasztott hétköznap reggeli (7 óra 30 perc) és déli (12 óra) időszakban végeztük, ahol a csúcsidőn belüli és a csúcsidőn kívüli forgalmi viszonyokat vettük figyelembe, a minden esetben adott kiinduló állomásról számítva. Természetesen a kapott eredmények nem mindegyik menetrend alkalmával fordultak elö (többek között az ekkor tapasztalható zsúfoltság, baleseti forgalmi dugók miatt), ezért az eltérő esetekben a lehető legközelibb indulási időpontot vizsgáltuk.

A közlekedési formák figyelembevételével készült táblázatokban a kiindulási helyszínek az elővárosok és községek hipotetikus, ugyanakkor a településközponthoz lehető legközelebb eső részei voltak, míg célállomásnak a budapesti Clark Ádám teret választottuk ki, amely mind a mai napig a magyarországi egyszámjegyü foútvonalak (továbbá a 10, 11, 31. sz. föutaké is) érvényben lévő kiindulópontja.

\section{Módszertan}

Budapest a hazai és az európai összehasonlításban nézve is társadalmi-gazdasági túlsúllyal bír és többszörös centrumnak tekinthető. Mivel a főváros az agglomeráció, a Közép-magyarországi régió és több szempontból a Kárpát-medence központjának is tekinthetö, a gyorsforgalmi úthálózat és ezen belül a közlekedési infrastruktúra fejlesztései rendkívül hangsúlyosak. A közúthálózat fejlesztésével nemcsak Budapest, de az ország időtere is folyamatosan csökken, azaz az országon belül egyre inkább rövidül az elérhetőségi tér, ahol a fővárosi méret 
növekedése csak a lassabb belvárosi haladási sebesség miatt következik be. A személygépjármü-állomány növekedésével - ami az életminőség indikátorának is tekinthető az egyéni közlekedés szerepe is jelentősen felértékelődött.

A közlekedés-földrajzi elemzésem során három, az agglomerációs településről a fővárosba tartó közlekedési irányt határoztunk meg az átláthatóság, ugyanakkor az idöben (perc) lehetö legrövidebb eljutás érdekében:

- $\quad$ vasút (MÁV) és/vagy a fővárosi közösségi közlekedés (BKK) használatával;

- Budapesti Helyiérdekü Vasút (BHÉV) és/vagy távolsági autóbusz közlekedés (Volánbusz Zrt.) és/vagy a fővárosi közforgalmú közlekedés (BKK) használatával;

- gépjármü használatával.

Számításba kellett venni továbbá, hogy mind a közforgalmú, mind pedig az egyéni közlekedés esetében felmerülhettek olyan differenciák, amikor az idő- és térparaméter kiugró különbségeket mutatott. Ekkor a hosszabb úton közlekedő járművek értek hamarabb célt, azaz hiába volt adott egy, a távolságban mért rövidebb bejutási lehetőség, amennyiben az - például a zsúfoltságból fakadóan - jelentős időbeli veszteségeket okozott. Ezekben az esetekben a leggyorsabb megközelítést helyeztük előtérbe, vagyis a lehető legrövidebb elérési idővel kalkuláltunk, a fentebb említett közlekedési alternatívákat figyelembe véve.

Vizsgálatunk következő lépésében a két feltételezett időpontra vonatkozóan átlagszámítást végeztünk annak érdekében, hogy kerekítsük a menetidők értékeit és közelítsük őket egy köztes időponthoz. Ennek köszönhetően kaptuk meg a napi átlagos elérési időket a távolságok feltüntetésével. Ennek folytatásaként az agglomerációs településeket rangsoroltuk abból a célból, hogy a települések elérési idejének és távolságának pontszámait a későbbiekben összesíteni tudjuk. A pontszámokat csökkenő sorrendben határoztuk meg, vagyis a Budapest központi részébe leggyorsabban bejutó közlekedési alternatívák települései kapták a legtöbb, míg a leghosszabb menetidőkkel rendelkezők a legkevesebb pontszámot, vagyis az adott kategóriában legjobb pozícióban lévő település 80, míg a leggyengébb pozícióban lévő település 1 pontot kapott.

A táblázatok véglegesítése után a kiugró értékek elkerülése végett a pontozásos módszer számítását két esetre kellett felosztanunk. A vasúti közlekedés léte vagy hiánya 40-40 darab településen jelentett volna előnyösebb, illetve hátrányosabb státuszt egy adott város vagy község számára. Ennek megfelelően kétféle kimutatást hoztunk létre, ahol a vasút figyelembevételével vagy a vasút nélkülözésével összesítettük a közlekedési módok után kapott rangsorokat. Előbbi esetében a csökkenő sorrendnek megfelelö következő számot adtuk hozzá a település értékeihez, míg utóbbi esetében ezek az értékek nem kerültek rögzítésre. Számszerüsítve a fentebb leírtakat: A vasúti forgalommal nem elérhető 40 darab város vagy község az első oszlopban 40-40 pontot kapott (az elérhetőségi időért és a távolságért), ugyanis a sorrendiséget és az egyenlőség elvét figyelembe véve ezeket a pontszámokat hozzá lehet rendelni a táblázathoz. A második variációban ezzel szemben ezekkel a hipotetikus értékekkel nem számolhatunk.

Az aggregálást követően alakul ki szektoronkénti felosztásban a rangsorolt, csökkenő sorrendben feltüntetett agglomerációs települések táblázata, amelyben piros színnel tüntettük fel azokat a helységeket, ahol nem állnak meg a vasúti szerelvények (1. táblázat). 
1. táblázat: Az agglomerációs települések rangsor szerinti sorrendje az elérési idők alapján, 2016.

\begin{tabular}{|c|c|c|c|}
\hline Település & $\begin{array}{c}\text { Rangsor összesen } \\
\text { vasúttal }\end{array}$ & Település & $\begin{array}{c}\text { Rangsor összesen } \\
\text { vasút nélkül }\end{array}$ \\
\hline Budaörs & 476 & Budaörs & 476 \\
\hline Törökbálint & 461 & Törökbálint & 461 \\
\hline Üröm & 433 & Üröm & 433 \\
\hline Dunakeszi & 421 & Dunakeszi & 421 \\
\hline Diósd & 412 & Diósd & 412 \\
\hline Solymár & 412 & Solymár & 412 \\
\hline Fót & 402 & Fót & 402 \\
\hline Biatorbágy & 396 & Biatorbágy & 396 \\
\hline Budakeszi & 390 & Érd & 387 \\
\hline Remeteszőlös & 390 & Vecsés & 386 \\
\hline Érd & 387 & Pilisvörösvár & 354 \\
\hline Vecsés & 386 & Herceghalom & 341 \\
\hline Budakalász & 375 & Gyál & 337 \\
\hline Pilisborosjenő & 360 & Dunaharaszti & 330 \\
\hline Nagykovácsi & 359 & Tárnok & 317 \\
\hline Pilisvörösvár & 354 & Pécel & 314 \\
\hline Csömör & 350 & Budakeszi & 310 \\
\hline Pomáz & 348 & Remeteszőlős & 310 \\
\hline Herceghalom & 341 & Ecser & 308 \\
\hline Gyál & 337 & Budakalász & 295 \\
\hline Kistarcsa & 332 & Göd & 294 \\
\hline Dunaharaszti & 330 & Csomád & 284 \\
\hline Telki & 328 & Pilisborosjenő & 280 \\
\hline Tárnok & 317 & Nagykovácsi & 279 \\
\hline Páty & 316 & Csömör & 270 \\
\hline Kerepes & 315 & Üllő & 269 \\
\hline Pécel & 314 & Pomáz & 268 \\
\hline Nagytarcsa & 310 & Gödöllő & 261 \\
\hline Ecser & 308 & Kistarcsa & 252 \\
\hline Pilisszentiván & 296 & Maglód & 250 \\
\hline Szentendre & 296 & Taksony & 250 \\
\hline Halásztelek & 295 & Telki & 248 \\
\hline Göd & 294 & Sződliget & 245 \\
\hline Csomád & 284 & Páty & 236 \\
\hline Mogyoród & 271 & Kerepes & 235 \\
\hline Szigetszentmiklós & 271 & Piliscsaba & 235 \\
\hline Üllö & 269 & Százhalombatta & 233 \\
\hline Budajenö & 267 & Veresegyház & 230 \\
\hline Gödöllő & 261 & Nagytarcsa & 230 \\
\hline Maglód & 250 & Felsőpakony & 230 \\
\hline Taksony & 250 & Pilisszentiván & 216 \\
\hline Sóskút & 248 & Szentendre & 216 \\
\hline Sződliget & 245 & Halásztelek & 215 \\
\hline Alsónémedi & 242 & Isaszeg & 212 \\
\hline Szigethalom & 237 & Gyömrö & 208 \\
\hline Piliscsaba & 235 & Sződ & 197 \\
\hline
\end{tabular}




\begin{tabular}{|c|c|c|c|}
\hline Százhalombatta & 233 & Mogyoród & 191 \\
\hline Veresegyház & 230 & Szigetszentmiklós & 191 \\
\hline Felsőpakony & 230 & Pilisjászfalu & 190 \\
\hline Perbál & 229 & Budajenő & 187 \\
\hline Tök & 224 & Vác & 170 \\
\hline Csobánka & 221 & Örbottyán & 169 \\
\hline Zsámbék & 219 & Dunavarsány & 169 \\
\hline Pilisszántó & 217 & Sóskút & 168 \\
\hline Szada & 213 & Ócsa & 167 \\
\hline Isaszeg & 212 & Erdőkertes & 166 \\
\hline Gyömrő & 208 & Alsónémedi & 162 \\
\hline Leányfalu & 203 & Szigethalom & 157 \\
\hline Sződ & 197 & Perbál & 149 \\
\hline Pusztazámor & 195 & Csörög & 148 \\
\hline Tököl & 190 & Tök & 144 \\
\hline Pilisjászfalu & 190 & Csobánka & 141 \\
\hline Vác & 170 & Zsámbék & 139 \\
\hline Örbottyán & 169 & Vácrátót & 138 \\
\hline Dunavarsány & 169 & Pilisszántó & 137 \\
\hline Ócsa & 167 & Szada & 133 \\
\hline Erdőkertes & 166 & Délegyháza & 130 \\
\hline Tahitótfalu & 165 & Leányfalu & 123 \\
\hline Tinnye & 159 & Pusztazámor & 115 \\
\hline Pilisszentlászló & 149 & Tököl & 110 \\
\hline Csörög & 148 & Tahitótfalu & 85 \\
\hline Pilisszentkereszt & 140 & Tinnye & 79 \\
\hline Vácrátót & 138 & Pilisszentlászló & 69 \\
\hline Délegyháza & 130 & Pilisszentkereszt & 60 \\
\hline Dunabogdány & 118 & Dunabogdány & 38 \\
\hline Pócsmegyer & 104 & Pócsmegyer & 24 \\
\hline Majosháza & 103 & Majosháza & 23 \\
\hline Kisoroszi & 96 & Kisoroszi & 16 \\
\hline Szigetmonostor & 93 & Szigetmonostor & 13 \\
\hline Visegrád & 93 & Visegrád & 13 \\
\hline
\end{tabular}

Forrás: Saját szerkesztés, 2016.

A vizsgált indikátorok kiválóan mutatják, hogy a Közép-magyarországi régió agglomerációs települései milyen eltérést produkálnak egy mutató hozzárendelésekor vagy annak figyelembe vétele nélkül. A táblázatban jól látható, hogy melyek azok az elővárosok, amelyek esetében a vasúti közlekedés hiánya kisebb, vagy nagyobb hatást gyakorolt a megközelíthetőségre.

Ezt követően ismét felosztottuk a településeket az agglomerációs szektorok szerint, ugyanis ennek a kategorizálási módszernek köszönhetően válik áttekinthetővé a térség közlekedési modellje és esetleges hierarchikus felépítése. Tanulmányunk erre vonatkozó fejezete egyben az eredmények ismertetését is magába foglalja. 
Eredmények (A budapesti agglomeráció településeinek szektoronkénti elemzése)

\section{Északi szektor}

\begin{tabular}{|l|l|c|l|c|}
\hline \multirow{5}{*}{} & Település & $\begin{array}{c}\text { Rangsor } \\
\text { összesen } \\
\text { vasúttal }\end{array}$ & Település & $\begin{array}{c}\text { Rangsor } \\
\text { összesen } \\
\text { vasút } \\
\text { nélkül }\end{array}$ \\
\hline \multirow{5}{*}{$\begin{array}{c}\text { Északi } \\
\text { szektor }\end{array}$} & Dunakeszi & $\mathbf{4 2 1}$ & Dunakeszi & $\mathbf{4 2 1}$ \\
\cline { 2 - 5 } & Fót & $\mathbf{4 0 2}$ & Fót & $\mathbf{4 0 2}$ \\
\cline { 2 - 5 } & Göd & $\mathbf{2 9 4}$ & Göd & $\mathbf{2 9 4}$ \\
\cline { 2 - 5 } & Csomád & $\mathbf{2 8 4}$ & Csomád & $\mathbf{2 8 4}$ \\
\cline { 2 - 5 } & Szöd & $\mathbf{1 9 7}$ & Sződd & $\mathbf{2 4 5}$ \\
\cline { 2 - 5 } & Vác & $\mathbf{1 7 0}$ & Vác & $\mathbf{1 9 7}$ \\
\cline { 2 - 5 } & Örbottyán & $\mathbf{1 6 9}$ & Örbottyán & $\mathbf{1 6 9}$ \\
\cline { 2 - 5 } & Csörög & $\mathbf{1 4 8}$ & Csörög & $\mathbf{1 4 8}$ \\
\cline { 2 - 5 } & Vácrátót & $\mathbf{1 3 8}$ & Vácrátót & $\mathbf{1 3 8}$ \\
\hline
\end{tabular}

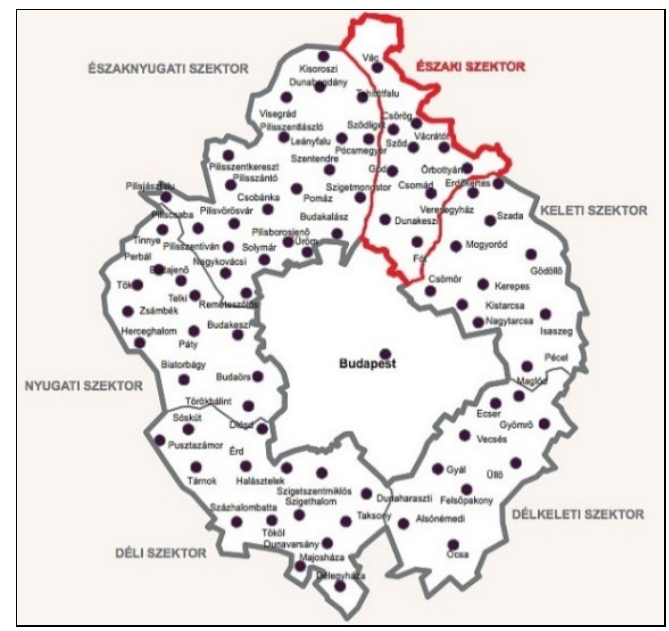

\section{1. ábra: A budapesti agglomeráció északi szektorának települései az elérési idők alapján}

Forrás: Saját szerkesztés, 2016.

Amint a 2. táblázatban látható, az agglomeráció északi szektorának vezető települései közlekedési szempontból kiváló megközelíthetőséggel rendelkeznek, amelyben szerepet játszanak a történelmi szempontból is hangsúlyos 70. és a 71. sz. vasútvonalak. Az urbanizálódás folyamata a korabeli vasúti és vicinális szakaszok megépítésével kezdődött a térségben, amely egyben a népesség növekedését is eredményezte. Jól látható, hogy még a gyengébb eredményt produkáló városok és községek is rendelkeznek vasúti ellátottsággal, amely biztos közlekedési kapcsolatot jelent Budapest kerületeihez. A szektor egyetlen megyei jogú városának, Vácnak a kedvezőtlen értékét a távolságból fakadó alacsonyabb pontszám magyarázza, ugyanakkor elérhetőségi pozícióját egy hatékony közlekedésszervezési megoldás erősíti: napszaktól függően Z70-es jelzéssel zónázó vonat közlekedik Budapestig, a köztes megállóhelyeket nem érintve.

A középrétegek lakóhelyének számító szektorban elhatárolódik egy Duna menti települési „tengely”, amely a táblázatban előnyösebb pozíciókban lévő településeket foglalja magába: Dunakeszi, Göd, Sződliget és Fót. A közúti közlekedésben a helységenként közelebb és távolabb található M2-es gyorsforgalmi út jelenti a gyorsabb bejutást a fővárosba.

\section{Keleti szektor}

A II. számú, keleti szektor esetében (3. táblázat) már nagyobb eltérések mutatkoznak az északi szektorénál a rangszámok esetében, ugyanakkor az eredmények nem tükrözik hüen a valóságot (1. ábra). Habár az olyan települések, mint Csömör, Mogyoród és Kerepes - amelyeknek 19901996 között jelentősen növekedett a lakosságszámuk -, valamint a kizárólag a megyei kórháznak köszönhetően városi rangot kapott Kistarcsa nem rendelkeznek vasúti ellátottsággal, a közlekedésükben elfoglalt kedvező helyzetüket az M0-s autóút keleti szektorának szomszédsága, a sürü menetrenddel bíró autóbusz járatok és a HÉV-vonalak biztosítják. Utóbbi esetében a szerelvények Budapest-Örs Vezér tere és Gödöllő (H8), valamint Budapest-Örs Vezér tere és Csömör (H9) között szállítják az utasokat. 


\begin{tabular}{|l|l|c|l|c|}
\hline \multirow{1}{*}{ Település } & $\begin{array}{c}\text { Rangsor } \\
\text { összesen } \\
\text { vasúttal }\end{array}$ & Település & $\begin{array}{c}\text { Rangsor } \\
\text { összesen } \\
\text { vasút } \\
\text { nélkül }\end{array}$ \\
\hline \multirow{5}{*}{$\begin{array}{c}\text { Keleti } \\
\text { szektor }\end{array}$} & Csömör & $\mathbf{3 5 0}$ & Pécel & $\mathbf{3 1 4}$ \\
\cline { 2 - 5 } & Kistarcsa & $\mathbf{3 3 2}$ & Csömör & $\mathbf{2 7 0}$ \\
\cline { 2 - 5 } & Kerepes & $\mathbf{3 1 5}$ & Gödöllö & $\mathbf{2 6 1}$ \\
\cline { 2 - 5 } & Pécel & $\mathbf{3 1 4}$ & Kistarcsa & $\mathbf{2 5 2}$ \\
\cline { 2 - 5 } & Nagytarcsa & $\mathbf{3 1 0}$ & Kerepes & $\mathbf{2 3 5}$ \\
\cline { 2 - 5 } & Gödöllö & $\mathbf{2 7 1}$ & Veresegyház & $\mathbf{2 3 0}$ \\
\cline { 2 - 5 } & Veresegyház & $\mathbf{2 3 0}$ & Nagytarcsa & $\mathbf{2 3 0}$ \\
\cline { 2 - 5 } & Szada & $\mathbf{2 1 3}$ & Mogaszeg & $\mathbf{2 1 2}$ \\
\cline { 2 - 5 } & Isaszeg & $\mathbf{2 1 2}$ & Erdökertes & $\mathbf{1 6 6}$ \\
\cline { 2 - 5 } & Erdökertes & $\mathbf{1 6 6}$ & Szada & $\mathbf{1 3 3}$ \\
\hline
\end{tabular}

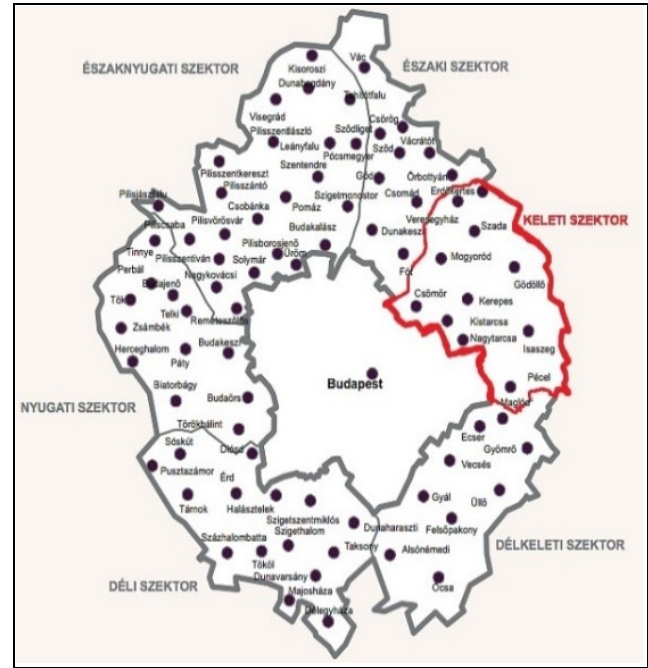

2. ábra: A budapesti agglomeráció keleti szektorának települései az elérési idők alapján

Forrás: Saját szerkesztés, 2016.

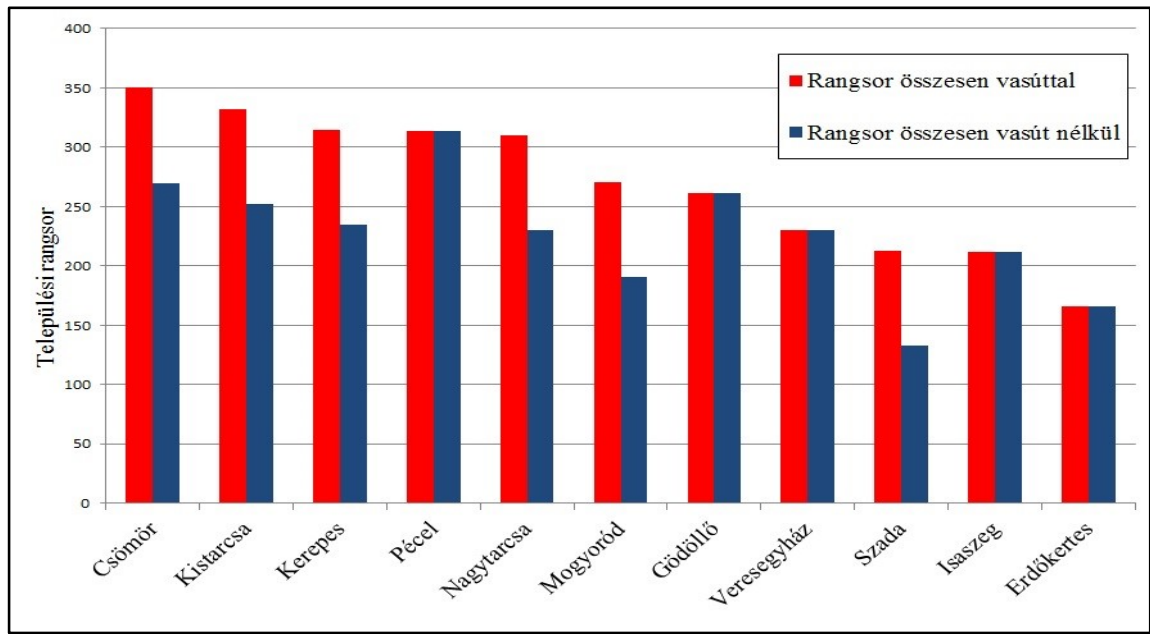

3. ábra: A keleti szektor agglomerációs települési rangsora az elérési idők szerint Forrás: Saját szerkesztés, 2016.

Idegenforgalmi szempontból kulcsfontosságú szereplönek számít a Mogyoród és Kerepes Szilasliget településrészének határában található, 1986-ban épített Hungaroring versenypálya, amely egy naptári évben több jelentős hazai és nemzetközi motoros- és autós (pl.: Formula-1 Magyar Nagydíj) rendezvényeknek ad otthont. A pálya a gépjármüvel nem rendelkező szurkolók számára is könnyen elérhető az események megrendezésekor, mivel a közelben fekvő települések autóbusz- és HÉV-járatait módosított menetrendek szerint és akár új megállóhelyek létesítésével közlekedtetik.

Gödöllö, mint a szektor központja és a budapesti agglomeráció rangos bolygóvárosa ${ }^{1}, 2015$ ben 32720 lakossal rendelkezett és több szempontból is - Pécellel és Veresegyházzal egyetemben - a térség egyik legjobb forgalmi helyzetü városának számított.

\footnotetext{
${ }^{1}$ Bolygóváros: Olyan, a központi várostól nem messze található, közepes, vagy nagy népességgel rendelkező város, mely átveszi a centrum városának néhány fontosabb szerepkörét.
} 
A személygépkocsival való kiváló elérhetőségét leginkább az 1978-ban átadott M3-as autópálya határozza meg, amely építésekor a környező településekre is térségfejlesztő hatást gyakorolt. Ilyen község például Szada (kb. 5 perc, 3,3 km) is, amely a sztráda közelségének köszönhetően tudja ellensúlyozni a vasúti közlekedés hiányából fakadó hátrányos helyzetét. Erdőkertes (kb. 8,8 km, 14 perc) és Isaszeg (kb. 10,5 km, 13 perc) esetében ugyanakkor éppen ellentétes ez az állapot, ugyanis ezek a települések távolabb esnek a legközelebbi autópályafelhajtótól, ennek következtében az elérési idejüket is inkább a vasút és a közforgalmú közlekedés eredményei tudják potenciálisan csökkenteni.

Délkeleti szektor

\begin{tabular}{|c|l|c|l|c|}
\hline \multirow{7}{*}{ Település } & $\begin{array}{c}\text { Rangsor } \\
\text { összesen } \\
\text { vasúttal }\end{array}$ & Település & $\begin{array}{c}\text { Rangsor } \\
\text { összesen } \\
\text { vasút } \\
\text { nélkül }\end{array}$ \\
\hline \multirow{5}{*}{$\begin{array}{c}\text { Délkeleti } \\
\text { szektor }\end{array}$} & Vecsés & $\mathbf{3 8 6}$ & Vecsés & $\mathbf{3 8 6}$ \\
\cline { 2 - 5 } & Gyál & $\mathbf{3 3 7}$ & Gyál & $\mathbf{3 3 7}$ \\
\cline { 2 - 5 } & Ecser & $\mathbf{3 0 8}$ & Ecser & $\mathbf{3 0 8}$ \\
\cline { 2 - 5 } & Üllö & $\mathbf{2 6 9}$ & Üllő & $\mathbf{2 6 9}$ \\
\cline { 2 - 5 } & Maglód & $\mathbf{2 5 0}$ & Maglód & $\mathbf{2 5 0}$ \\
\cline { 2 - 5 } & Alsónémedi & $\mathbf{2 4 2}$ & Felsőpakony & $\mathbf{2 3 0}$ \\
\cline { 2 - 5 } & Felsőpakony & $\mathbf{2 3 0}$ & Gyömrö & $\mathbf{2 0 8}$ \\
\cline { 2 - 5 } & Gyömrö & $\mathbf{2 0 8}$ & Ócsa & $\mathbf{1 6 7}$ \\
\cline { 2 - 5 } & Ócsa & $\mathbf{1 6 7}$ & Alsónémedi & $\mathbf{1 6 2}$ \\
\hline
\end{tabular}

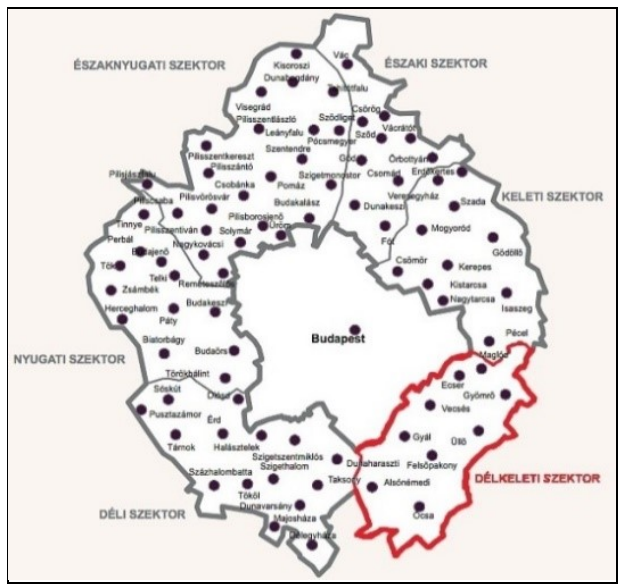

\section{4. ábra: A budapesti agglomeráció délkeleti szektorának települései az elérési idők alapján}

Forrás: Saját szerkesztés, 2016.

A Liszt Ferenc nemzetközi repülőtér szomszédságában fekvő, eredetileg a fővárosi gyártelepek ingázó munkásai által lakott települések társadalmi polarizáltsága ma is meghatározó a szektorban (4. táblázat).: „Az agglomeráció falusi miliőbe ágyazott munkás- és kisvállalkozói lakóhelye az alföldi szektor." (Beluszky (2007). Közlekedési szempontból ugyanakkor - az északi szektor vasúti közlekedéssel ellátott részeihez hasonlóan - történtek előremutató fejlesztések az elmúlt évtizedekben, amelynek hatására a települések hatékonyan tudtak a fóvároshoz kapcsolódni. Ez egyrészt a 100. és a 120. sz. vasúti fővonalaknak, másrészt az M0s körgyürünek, a 4. számú fơút 2x2 sávos szakaszának és az M5-ös autópálya csomópontjainak köszönhető. Kivételt a térség egy-egy déli városa (Ócsa) és nagyközsége (Alsónémedi) jelenti, amelyek a nagysebességú útvonalaktól való távolság miatt és - utóbbi esetében - a vasút hiányából fakadóan hátrányosabb besorolásba kerültek.

\section{Déli szektor}

Budapest vonzáskörzetének 15 települést magába foglaló déli szektora igencsak változatos képet mutat a rangsorok összehasonlításában (5. táblázat). A sorrendben első négy település az egész agglomerációban kitüntetett elérhetőségi idővel bír és kiváló közlekedési kapcsolatot tart fenn a főváros belső részeivel. Az utazni vágyók vasúttal, HÉV-vel, elővárosi autóbusszal, távolsági Volán-járatokkal és az egyéni közlekedés ismert eszközeivel juthatnak a budapesti centrumba. Taksony, Százhalombatta, Dunavarsány és Délegyháza esetében tisztán látszik, hogy csak a vasúti forgalom miatt lehetséges jobb besorolásba rendezni ezeket a településeket, 
mert a személygépkocsival való elérhetőségük nem mondható kedvezőnek. Pusztazámort és Sóskutat azonban már a vasút is elkerüli, ezért esetükben csak az M7-es autópálya közelsége lehet alternatívája a gyors megközelíthetőségnek.

\begin{tabular}{|l|l|c|l|c|}
\hline \multirow{7}{*}{ Település } & $\begin{array}{c}\text { Rangsor } \\
\text { összesen } \\
\text { vasúttal }\end{array}$ & \multicolumn{1}{|c|}{ Település } & $\begin{array}{c}\text { Rangsor } \\
\text { összesen } \\
\text { vasút } \\
\text { nélkül }\end{array}$ \\
\hline \multirow{7}{*}{$\begin{array}{c}\text { Déli } \\
\text { szektor }\end{array}$} & Diósd & $\mathbf{4 1 2}$ & Diósd & $\mathbf{4 1 2}$ \\
\cline { 2 - 5 } & Érd & $\mathbf{3 8 7}$ & Érd & $\mathbf{3 8 7}$ \\
\cline { 2 - 5 } & Dunaharaszti & $\mathbf{3 3 0}$ & Dunaharaszti & $\mathbf{3 3 0}$ \\
\cline { 2 - 5 } & Tárnok & $\mathbf{3 1 7}$ & Tárnok & $\mathbf{3 1 7}$ \\
\cline { 2 - 5 } & Saksony & $\mathbf{2 9 5}$ & Taksony & $\mathbf{2 5 0}$ \\
\cline { 2 - 5 } & Sóskút & $\mathbf{2 5 0}$ & Halásztelek & $\mathbf{2 1 5}$ \\
\cline { 2 - 5 } & Szigethalom & $\mathbf{2 3 7}$ & Szigetszentmiklós & $\mathbf{1 9 1}$ \\
\cline { 2 - 5 } & Százhalombatta & $\mathbf{2 3 3}$ & Dunavarsány & $\mathbf{1 6 9}$ \\
\cline { 2 - 5 } & Pusztazámor & $\mathbf{1 9 5}$ & Szigethalom & $\mathbf{1 6 8}$ \\
\cline { 2 - 5 } & Tököl & $\mathbf{1 9 0}$ & Délegyháza & $\mathbf{1 3 7}$ \\
\cline { 2 - 5 } & Dunavarsány & $\mathbf{1 6 9}$ & Pusztazámor & $\mathbf{1 1 5}$ \\
\cline { 2 - 5 } & Délegyháza & $\mathbf{1 3 0}$ & Tököl & $\mathbf{1 1 0}$ \\
\cline { 2 - 5 } & Majosháza & $\mathbf{1 0 3}$ & Majosháza & $\mathbf{2 3}$ \\
\hline
\end{tabular}

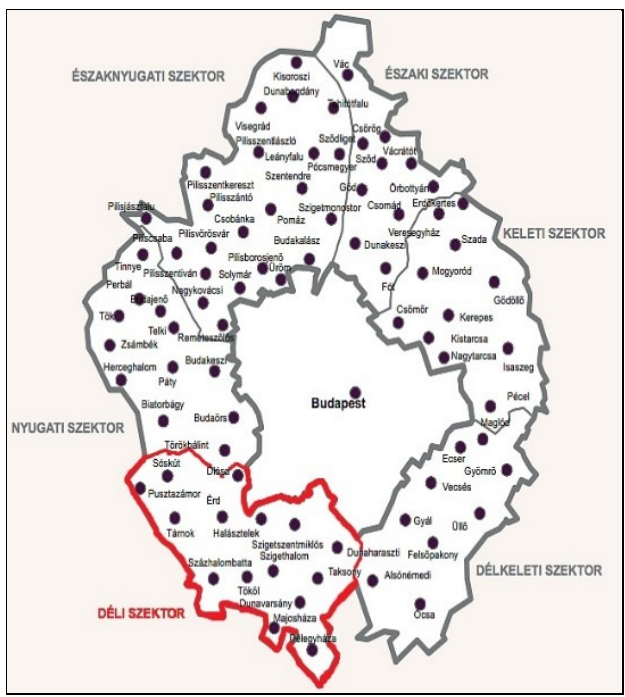

\section{5. ábra: A budapesti agglomeráció déli szektorának települései az elérési idők alapján} Forrás: Saját szerkesztés, 2016.

Mindemellett a ráckevei HÉV három további települést (Szigetszentmiklós, Szigethalom, Tököl) is érint útja során, ezáltal csúcsidőben felveszi a versenyt a közúti közlekedéssel. A rangsor végén található Majosháza azonban minden szempontból hátrányos helyzetű szereplő a szektor elérhetőségi vizsgálatában, ugyanis jelentős időveszteséget okozva - négy buszjárat kivételével - átszállásra kényszeríti az utasokat Budapest határán kívül. A község megközelíthetősége a szomszédos Délegyházánál és Dunavarsánynál is rosszabb, mivel a Ráckevei-(Soroksári) Duna partján fekvő települést épp hogy csak, de elkerülik a vasút- és HÉV-vonalak.

\section{Nyugati szektor}

A Budai-hegység déli lábánál fekvő agglomerációs települések nemcsak a térség, de az ország szempontjából is alapvető gazdasági súllyal rendelkeznek. A nyugati szektor elővárosai az agglomeráció hierarchiájának csúcsán találhatóak, ugyanis ezekben a térségekben teljesedett ki leginkább az 1980-as évektől kezdődő lakossági és gazdasági szuburbanizáció.

Budakeszi a nyugati szektor magas presztízsű, átalakulóban lévő alvóvárosa² ${ }^{2}$ ahol már érezhető az gyorsforgalmi utaktól és a vasúti vonalaktól mért távolság, valamint a csúcsidőszakban jellemző zsúfoltság. A településen ezért az elővárosi és a Volán autóbusz-közlekedést fejlesztették az elmúlt évtizedekben, hogy gyors elérhetőséget biztosítsanak a budapesti Széll

\footnotetext{
2 Alvóváros: Lakóhely funkciójú városok, amelyek népessége a központban vagy a közeli bolygóvárosban dolgozik.
} 
Kálmán és Széna térre. A lista második felében szereplő települések szintén csak autóbusszal és gépjármüvel érhetőek el a lehető leggyorsabban, ami a kimutatás adataiból is látható.

\begin{tabular}{|c|l|c|l|c|}
\hline Település & $\begin{array}{c}\text { Rangsor } \\
\text { összesen } \\
\text { vasúttal }\end{array}$ & Település & $\begin{array}{c}\text { Rangsor } \\
\text { összesen } \\
\text { vasút } \\
\text { nélkül }\end{array}$ \\
\hline \multirow{5}{*}{$\begin{array}{c}\text { Nyugati } \\
\text { szektor }\end{array}$} & Budaörs & $\mathbf{4 7 6}$ & Budaörs & $\mathbf{4 7 6}$ \\
\cline { 2 - 5 } & Törökbálint & $\mathbf{4 6 1}$ & Törökbálint & $\mathbf{4 6 1}$ \\
\cline { 2 - 5 } & Biatorbágy & $\mathbf{3 9 6}$ & Biatorbágy & $\mathbf{3 9 6}$ \\
\cline { 2 - 5 } & Budakeszi & $\mathbf{3 9 0}$ & Herceghalom & $\mathbf{3 4 1}$ \\
\cline { 2 - 5 } & Herceghalom & $\mathbf{3 4 1}$ & Budakeszi & $\mathbf{3 1 0}$ \\
\cline { 2 - 5 } & Péti & $\mathbf{3 2 8}$ & Telki & $\mathbf{2 4 8}$ \\
\cline { 2 - 5 } & Budajenö & $\mathbf{3 1 6}$ & Páty & $\mathbf{2 3 6}$ \\
\cline { 2 - 5 } & Perbál & $\mathbf{2 6 7}$ & Budajenö & $\mathbf{1 8 7}$ \\
\cline { 2 - 5 } & Tök & $\mathbf{2 2 4}$ & Perbál & $\mathbf{1 4 9}$ \\
\cline { 2 - 5 } & Zsámbék & $\mathbf{2 1 9}$ & Zsámbék & $\mathbf{1 3 9}$ \\
\cline { 2 - 5 } & Tinnye & $\mathbf{1 5 9}$ & Tinnye & $\mathbf{7 9}$ \\
\hline
\end{tabular}

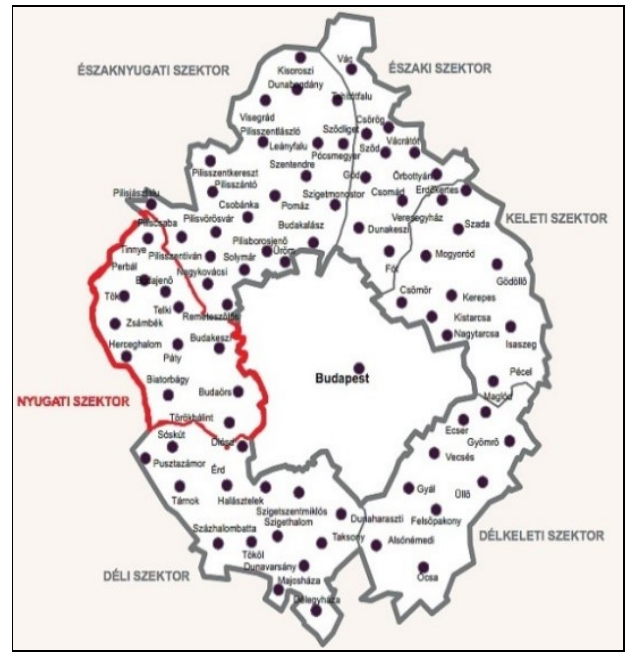

\section{6. ábra:A budapesti agglomeráció nyugati szektorának települései az elérési idők alapján}

Forrás: Saját szerkesztés, 2016.

A nyugati szektor elérhetőségi adatait a 6. táblázat mutatja be, melyből megállapítható, hogy Budaörs és Törökbálint gazdaságföldrajzi adottságai egyedülállóak, mivel a vonzáskörzet nyugati „városkapujaként”, valamint a multinacionális nagyvállalatok és gazdasági társaságok logisztikai központjaként jelenik meg a térségben, több esetben zöldmezős ${ }^{3}$ beruházások formájában. Mindemellett a 2015-ben 28045 fő lakosú város ingázási egyenlege gyakorlatilag nullának tekinthető, ami azt jelenti, hogy még a fövárosra is kiemelkedő munkaerővonzást tud gyakorolni (KSH, 2015). Elérhetőségi szempontból a rangsorban szereplő két város a 80 települést tekintve is listavezetö, vagyis Budaörsről és Törökbálintról lehet leggyorsabban és leghatékonyabban megközelíteni a föváros centrumát a vizsgált közlekedési eszközökkel, amint azt a 2. számú ábra is mutatja. Az 1. sz. vasúti fővonal, az M0-s autóút, valamint az M1M7 autópálya közös bevezető szakasza - a Budapesttől távolabb található Herceghalom és Biatorbágy esetében is - még csúcsidőben is kiváló megközelíthetőséget jelent a közlekedőknek.

\footnotetext{
3 Zöldmezős beruházás: Korábban mezőgazdasági művelés alatt álló földterület ipari felhasználásba vétele, teljesen új beruházás, új infrastruktúra és új épületek létrehozásával. Általában városok választják ezt a megoldást veszteséges vagy kihasználatlan mezőgazdasági területeik hasznosítása mellett új munkahelyek létrehozására, és új adóbevételi források kialakítása céljából. Ehhez kapcsolódó hír 2016-ban, hogy Magyarország kezdeményezte Pest megye önálló régióvá válását az Európai Bizottságnál 2018-tól. A kettéválasztás célja az, hogy a Budapesthez képest kevésbé fejlett Pest megyére kedvezőbb európai uniós támogatási feltételek legyenek érvényesek 2020 után. Ennek következtében az új régió - ezáltal az agglomeráció települései is - további zöldmezős beruházások fejlesztési helyszíneként tud szolgálni a főváros barnamezős beruházásaitól különállóan.
} 


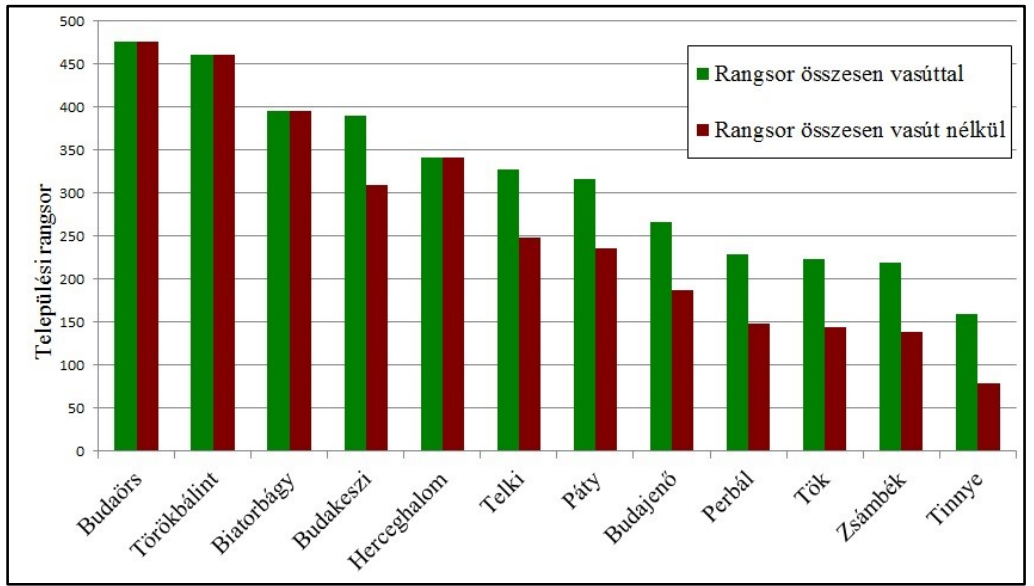

7. ábra:A nyugati szektor agglomerációs településeinek rangsora az elérési idők alapján

Forrás: Saját szerkesztés, 2016.

Északnyugati szektor

\begin{tabular}{|c|c|c|c|c|}
\hline & Település & $\begin{array}{l}\text { Rangsor } \\
\text { összesen } \\
\text { vasúttal }\end{array}$ & Település & $\begin{array}{c}\text { Rangsor } \\
\text { összesen } \\
\text { vasút } \\
\text { nélkül }\end{array}$ \\
\hline \multirow{23}{*}{$\begin{array}{c}\text { Északnyugati } \\
\text { szektor }\end{array}$} & Üröm & 433 & Üröm & 433 \\
\hline & Solymár & 412 & Solymár & 412 \\
\hline & Remeteszőlős & 390 & Pilisvörösvár & 354 \\
\hline & Budakalász & 375 & Remeteszőlős & 310 \\
\hline & Pilisborosjenő & 360 & Budakalász & 295 \\
\hline & Nagykovácsi & 359 & Pilisborosjenő & 280 \\
\hline & Pilisvörösvár & 354 & Nagykovácsi & 279 \\
\hline & Pomáz & 348 & Pomáz & 268 \\
\hline & Pilisszentiván & 296 & Piliscsaba & 235 \\
\hline & Szentendre & 296 & Pilisszentiván & 216 \\
\hline & Piliscsaba & 235 & Szentendre & 216 \\
\hline & Csobánka & 221 & Pilisjászfalu & 190 \\
\hline & Pilisszántó & 217 & Csobánka & 141 \\
\hline & Leányfalu & 203 & Pilisszántó & 137 \\
\hline & Pilisjászfalu & 190 & Leányfalu & 123 \\
\hline & Tahitótfalu & 165 & Tahitótfalu & 85 \\
\hline & Pilisszentlászló & 149 & Pilisszentlászló & 69 \\
\hline & Pilisszentkereszt & 140 & Pilisszentkereszt & 60 \\
\hline & Dunabogdány & 118 & Dunabogdány & 38 \\
\hline & Pócsmegyer & 104 & Pócsmegyer & 24 \\
\hline & Kisoroszi & 96 & Kisoroszi & 16 \\
\hline & Szigetmonostor & 93 & Szigetmonostor & 13 \\
\hline & Visegrád & 93 & Visegrád & 13 \\
\hline
\end{tabular}

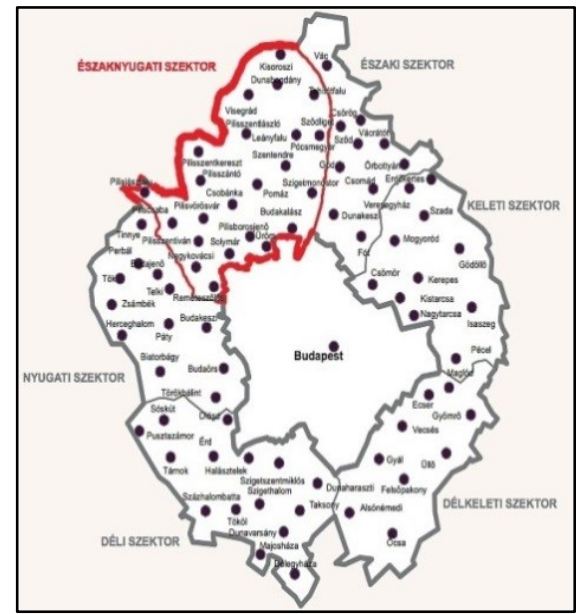

\section{8. ábra:A budapesti agglomeráció északnyugati szektorának települései az elérési}

Forrás: Saját szerkesztés, 2016. idők alapján

A huszonhárom, föleg lakófunkciójú települést magába foglaló északnyugati szektor közül csak öt települést érint közvetlenül vasútvonal. A 7. számú táblázatból kiderül, hogy a rangsorban első két helyezett, Üröm és Solymár a fövároshoz való közelségének, valamint a vizsgált közlekedési hálózatok gyorsaságának köszönhetően az egész budapesti vonzáskörzetben a legjobb elérhetőségi időkkel rendelkeznek. Itt található az a 2. sz. Budapest-Esztergom vasútvonal, amely további három települést (Pilisvörösvár, Piliscsaba, Pilisjászfalu) integrál az 
elővárosi közlekedéshálózatba. A szakasz a közelmúltban (2012-2015 között) az Európai Unió (85\%) támogatásából és hazai (15\%) finanszírozásból jelentős felújításon ment keresztül, 44,5 milliárd forint értékben. Ennek keretében modernizálták az infrastruktúrát (elektronikus jelzőés biztosítóberendezés, forgalomirányító központ átépítése, közúti felüljáró létesítése) és előkészítették a szakasz villamosítását is, amelyet 2016-2017-ben terveznek a szakemberek kivitelezni. A rekonstrukció eredményeként további menetidő csökkenésben bízhatnak az érintett térség lakosai (Nemzeti Infrastruktúra Fejlesztő Zrt., 2015).

A H5-ös HÉV a szektorban három városon halad keresztül (Budakalász, Pomáz, Szentendre), amely a versenyképes autóbusz- és egyéni közlekedés mellett a vasúti forgalom hiányából fakadó lehetséges negatívumokat is ellensúlyozni tudja. Ez az összefüggés olvasható ki a 3. számú ábrából is, mivel Pomáz vonatkozásában egyáltalán nem, Budakalász és Szentendre mint fö turisztikai célpontok - esetében pedig csak egy pozícióval romlik a vasút figyelembe vétele nélküli elérhetőségi rangsor a többi településhez képest. A fenti eredményhez természetesen az is hozzátartozik, hogy a többi agglomerációs város és község kedvezőtlen eredményeket produkált a megközelíthetöségi kutatásban.

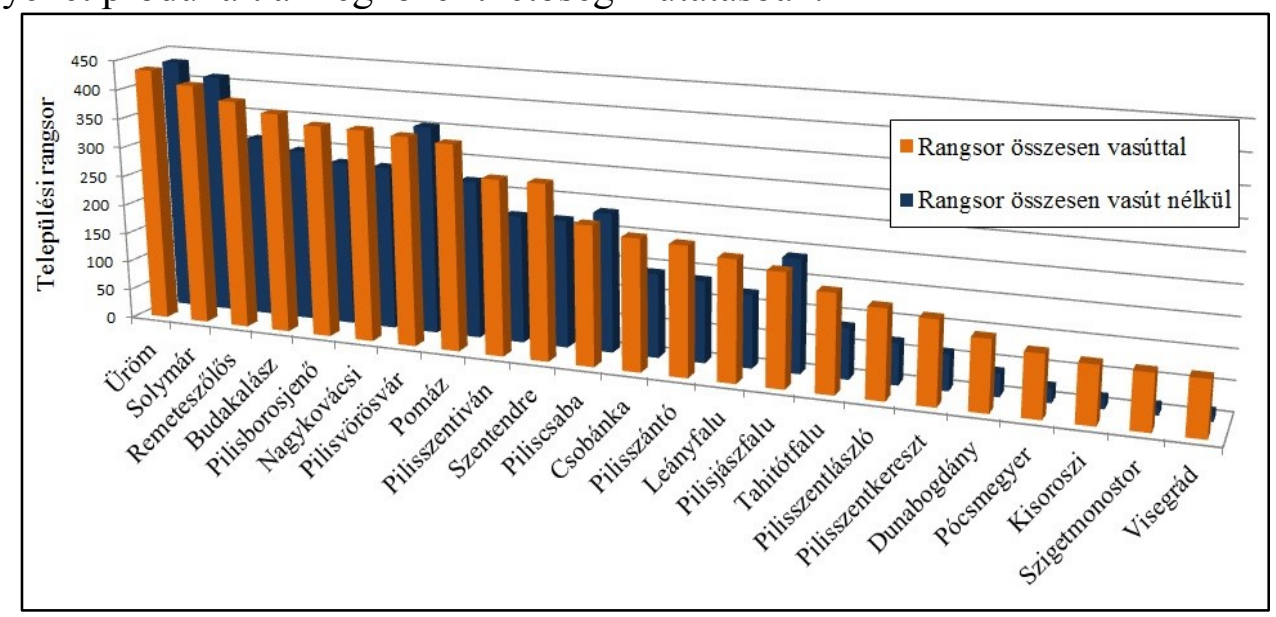

9. ábra: Az északnyugati szektor agglomerációs települései rangsora az elérhetőségi idők szerint

Forrás: Saját szerkesztés, 2016.

A piros színnel jelölt települések közül Remeteszőlős, Nagykovácsi és Pilisborosjenő községek az elővárosi autóbusz (BKK-Volán) járatokkal tudnak hatékonyabban a föváros közösségi közlekedéséhez kapcsolódni. A Budai-hegység további települései (Pilisszentiván, Csobánka, Pilisszántó, Pilisszentlászló, Pilisszentkereszt) a természetföldrajzi és funkcionális (rekreációs szerepkör, kertvárosi jelleg) viszonyokból eredően nem építettek ki fontosabb hálózatokat, ezért ebben a térségben a közúti szállítás (autóbusz és személygépkocsi) maradt a meghatározó közlekedési forma. Tahitótfalut, Leányfalut és Visegrádot is az országos autóbuszjáratokkal és gépjármüvel lehet elérni a 11. sz. föúton. Utóbbi esetében a torzító hatás elkerülése végett nem vettük figyelembe a naponta kora reggeltől estig, óránként közlekedő Visegrád-Nagymaros kompjáratot, amely a 70. sz. Budapest-Szob vasútvonallal teremt optimális kapcsolatot. A Dunán való átjutást biztosító kompot mellőző döntésnek és fővárostól való $40 \mathrm{~km}$ távolságnak köszönhetően került Visegrád a ranglista végére, azonban közlekedési kapcsolatai korántsem olyan hátrányosak, mint Pócsmegyeré, Kisoroszié és Szigetmonostoré. A Szentendrei-szigeten található három település közúton csupán a - budai oldal irányába - tahitótfalui hídról közelíthető meg, amely belső perifériát és egyben kitérőt jelent az utaskilométer és az időbeli távolság szempontjából. A korlátozott közúti elérhetőség további alternatívái a kisoroszi, surányi és szigetmonostori révátkelések, amelyek a - községenként - naponta kevesebb, mint nyolc induló autóbuszjárattal szemben fel tudják venni a versenyt. 


\section{Következtetések}

Főbb megállapításaink a budapesti agglomerációs települések közlekedési elérhetőségével kapcsolatban az alábbiak:

a) egy adott közlekedési mód kedvezőnek tekinthető elérési ideje erősíti, azonban nem biztosítja a kiválasztott település rangsorban való elsőrendủ pozícióját (pl.: Vác);

b) Budapesttől távolodva az agglomerációs települések elérhetőségi ideje a legtöbb esetben a közlekedési alternatívák teljesítményétől és csak kisebb hányadban a távolságtól függ;

c) több esetben azok a közlekedési eszközök (pl.: komp) jelentenek kedvezőbb elérhetőséget egy adott település számára, amelyeket az esetleges torzító hatásuk miatt volt szükséges kizárni a vizsgálatból (pl.: Visegrád);

d) a kiépített infrastruktúrák (autópálya-csomópontok, vasút- és HÉV-állomások) és az azokhoz való közelség minden esetben térségfejlesztő és az elérhetőséget javító tényezők (pl.: Törökbálint, Budaörs, Szentendre);

e) az elővárosok és a községek közlekedési elérhetőségét erősen befolyásolják a természetföldrajzi körülmények, amelyek relatív periférikus területeket hoznak létre (pl.: Szentendrei-sziget, Pilis települései);

f) az autópálya-felhajtók közelsége egyértelmúen növeli az érintett települések népességmegtartó és egyben bővülő erejét;

g) a vonalas infrastruktúra léte és a Budapesthez való kapcsolódási képesség jelentős mértékben meghatározza a térség területi versenyképességét.

Megállapítható továbbá, hogy a főváros vonzáskörzetének települései a heterogén természetföldrajzi viszonyokból, valamint a társadalmi-gazdasági-közlekedési fejlődési pályákból fakadóan eltérő forgalmi kapcsolatokat létesítettek a centrummal az elmúlt két évszázadban. A hátrányosabb helyzetü szektorok (pl.: északnyugati szektor) esetében a térségi kapcsolatok müszaki és infrastrukturális fejlesztéseit szükséges előtérbe helyezni (az említett szektor esetében például az M0 autóút északnyugati szektorának kiépítése), amelyben az elérhetőség javítása kulcsfontosságú paraméternek számít.

A budapesti agglomerációban a közlekedési infrastruktúra fejlesztése erősítené a szektorok térszerkezeti kohézióját, amelyek így nem kizárólag lakófunkciót biztosítanának az ott élöknek, hanem az erős gazdaságnak köszönhetően jobb megélhetést is. Ilyen települések közül már több is megtalálható a vonzáskörzetben, amelyek bolygóvárosként jelennek meg az elővárosi szektorokban (pl.: Dunaharaszti, Budaörs, Gödöllő, Vác). Budaörs esetében például egy városmag körül kialakuló (,edge-city”) növekedési pólust érdemes megemlíteni, amely a kisés közepes, valamint a multinacionális vállalatok telephelyéül szolgál és funkcionálisan sokszínü, dinamikusan fejlödő területet foglal magába. A kis- és nagykereskedelem megjelenésével a munkaerő elszívó hatása is jelentkezik, amely a mindennapi közlekedésben is érzékelhető. Ennek következtében ugyanis a helyi és az agglomerációból a föváros felé ingázó munkaerő helyben marad, amely tehermentesíti a csúcsidőben amúgy is zsúfolt elővárosi közlekedést. További előnye, hogy a Budapestről kifelé áramló munkaerő nem töri meg a település gazdasági fejlődését és a központi városból reggel kifelé, este befelé tartó forgalom kiegyensúlyozottabbá teszi a térség közlekedési struktúráját.

Ennek ellenére a fő közlekedési tengelyektől távol eső és a csúcsidőszakban - a zsúfoltságból fakadóan - hosszú megközelíthetőségi idejű közösségi és egyéni közlekedéssel sújtott településeken - akár a főváros szomszédságában is - stagnálás, vagy az átlagtól elmaradó fejlődés tapasztalható (pl. Szentendrei-sziget, Pilis települései). Ezekben a periférikus térségekben az infrastrukturális elérhetőségi nehézségeket a közúthálózat folyamatos 
fejlesztésével és karbantartásával lehet ellensúlyozni annak érdekében, hogy a települések versenyképesek maradjanak és fejlődésnek induljanak az agglomerációban.

\section{Irodalomjegyzék}

1. Beluszky P. (szerk.) (2007): Közép-Magyarország. In: Horváth Gy. (szerk.): A Kárpátmedence régiói. Pécs-Budapest Magyar Tudományos Akadémia Regionális Kutatások Központja, Dialóg Campus Kiadó., 6. kötet, 566 p.

2. Erdősi F. (2005): Magyarország közlekedési és távközlési földrajza. Budapest - Pécs, Dialóg Campus Kiadó, 504 p.

3. Mezei I. (szerk.) (2006): A magyar vasút krónikája a XX. században. Budapest, MÁV Zrt. Vezérigazgatóság, 420 p.

4. Perczel Gy. (szerk.) (2003): Magyarország társadalmi-gazdasági földrajza. Budapest, ELTE Eötvös Kiadó, 632 p.

5. 89/1997. (V. 28.) Kormányrendelet a budapesti agglomeráció, valamint a Balaton kiemelt üdülőkörzete lehatárolásáról

6. http://www.ksh.hu/docs/hun/xftp/idoszaki/mo telepuleshalozata/agglomeracio.pdf Letöltés: 2016.07.27.

7. https://www.ksh.hu/docs/hun/xstadat/xstadat eves/i_wdsd003b.html Letöltés: 2016.07.27.

8. http://nif.hu/2015/08/ujra-elindul-a-vonatkozlekedes-budapest-es-esztergom-kozott/ Letöltés: 2016.07.27.

9. http://futar.bkk.hu/?map=13/47.501/19.053\&layers=GSVB Letöltés: 2016.07.27.

10. http://ujmenetrend.cdata.hu/uj menetrend/volan/index.php Letöltés: 2016.07.27.

11. http://elvira.mav-start.hu/elvira.dll/Letöltés: 2016.07.27. 